Hassan Mohamed Hussein, Faculty of Commerce, Cairo University, Cairo, Egypt

\author{
Abeer A. Mahrous,
}

Faculty of Commerce, Cairo University, Cairo, Egypt

\title{
PERCEIVED SERVICE VALUE, CUSTOMER ENGAGEMENT AND BRAND LOYALTY IN HEALTH CARE CENTRES IN EGYPT
}

This study focused on examining the effect of Cengiz \& Kirkbir (2007)'s eight dimensions of perceived value on customer engagement and customer loyalty. Each of the eight dimensions of perceived service value has been studied separately in previous studies. Therefore, this research provides an integrative framework to examine the role all the dimensions of perceived service value in increasing customer engagement and loyalty in health care centres in Egypt. Healthcare centres were chosen because the degree of engagement in the service delivery process has started to increase in the past few years such as engaging the customers in the service delivery plan (e.g. Fitness Monthly Programs), the mechanism of positive/negative recommendation of specific healthcare centres to their friends and family, also to other random users on online social networks, and acquiring a high sense of belonging to their healthcare centre. This has resulted in a great degree of positive behavioural intentions. Also, the active mechanism of receiving complaints and involving the customers in its solving process has been applied in many health care centres. The study focused on the adolescents, youths and adults since they represent the majority of the healthcare centres users according to the context understudy (based on the exploratory research conducted). This research targeted 400 healthcare centres users. In addition, the moderation effect of the brand name of health care centre on the relationship between Hedonics and Customer Engagement was examined. Also, the moderating effect of age on the relationship between service quality and customer engagement was tested. Finally, the mediating effect of customer engagement mediates the relationship between control and customer loyalty was examined.

Keywords: value, customer, engagement, brand, loyalty, health care centres.

Introduction. This paper focuses on empirically examining the role of perceived service value in enhancing customer engagement and loyalty. Each of the eight dimensions of perceived service value has been studied separately in previous studies. Therefore, this research provides an integrative framework to examine the role all the dimensions of perceived service value in increasing customer engagement and loyalty in health care centres in Egypt. Healthcare centres were chosen because the degree of engagement in the service delivery process has started to increase in the past few years such as engaging the customers in the service delivery plan (e.g. Fitness Monthly Programs), the mechanism of positive/negative recommendation of specific healthcare centres to their friends and family, also to other random users on online social networks, and acquiring a high sense of belonging to their healthcare centre. This has resulted in a great degree of positive behavioural intentions. Also, the active mechanism of receiving complaints and involving the customers in its solving process has been applied in many health care centres. 
Literature review. Customer Engagement (CE). Customer engagement is conceptualized as having cognitive, emotional, and behavioural aspects (Brodie et al., 2011; Wong \& Merrilees, 2015). Van Doorn et al. (2010) defined customer engagement as the clients' behavioral expression in relation to the brand or the firm, beyond purchasing, emerging from motivational drivers. CE contains a huge cluster of behaviours encompassing word-of-mouth (WOM) attention, recommendations, helping another client, blogging, including reviews, and even involving in lawful action.

The behavioural expressions, other than purchasing can be both affirmative (i.e., posting an affirmative brand memo on a blog) and negative (i.e., coordinating actions opposing firm). CE also involves customer co-creation. Lusch and Vargo (2006) referred to customer co-creation as the involvement of the client in the conception of the main offering. It can appear as across public conception, co-design, or collective fabrication of the goods". Therefore, co-creation happens once the customer participates through unprompted, flexible behaviors that distinctively tailor the customer-to-brand experience. According to Van Dorn et al. (2010), behaviors like making recommendations to develop the consumption know-how, aiding and coaching service providers, and aiding other customers to use the best of the service provided are all characteristics of co-creation, and therefore customer engagement behaviors.

Perceived Value. Dimensions of Perceived Value. Recent literature defined perceived value as a multidimensional concept. Virvilaite et al. (2015) suggest it can be explored through three dimensional: functional, emotional and social value. Meanwhile, Cengiz \& Kirkbir (2007) proposed that perceived value is a multidimensional formative construct made up of eight dimensions, which are a functional value (installation, service quality, price, and professionalism), emotional value (Novelty, control, and hedonics) and social value. This study adopts the eight dimensions of Cengiz and Kirkbir (2007), as it is the most explanatory and detailed classification of the value perceived by the consumer while experiencing any service.

Functional Dimensions. Cengiz \& Kirkbir (2007) concluded that functional values are more important than emotional and communal ones in healthcare services. It was also found in their research that control plays a momentous act in the assessment process. Providing a client opinion to select from is a competent method of enhancing an individual's sense of manipulation and therefore satisfaction alongside the experience. Clients are pursuing a nature in that they possess options to select from and whereas they discern possessing a sense of control. The impact of novelty on overall satisfaction and value seems to vary based on respondent characteristics. Thus, we hypothesize:

H1: Installation as a Functional Perceived Value Dimension is associated with Customer Engagement

H2: Price as a Functional Perceived Value Dimension is associated with Customer Engagement.

H3: Professionalism as a Functional Perceived Value Dimension is associated with Customer Engagement.

Meanwhile, Service quality is generally viewed as the output of the service delivery service systems (Akhade et al., 2013). Customer perceived value discovers the communication between the product and service, while service quality commonly focuses on the product or service, i.e. what the business provided. (Akhade, G., 2013). Chen \& Hu (2009)'s study broadens prior studies by confirming that determinant attributes of service quality can impact customers' functional value and symbolic value. The reading proved a significant relationship between determinant characteristics of service quality and perceived value.

Several studies examined the relationship between service quality and more behavioral intentions. In previous literature, (Parasuraman, Zeithaml, and Berry 1991) a significant association between customers' perceptions of service quality and their willingness to endorse the company was found. Zeithaml et al. (1996) stated another aspect of service provision that can impact behavioral intentions involves the problematic experience of customers. Once customers encounter service problems, these experiences are probable to affect behavioral intentions adversely. Though, the influence of problem resolution on 
customers' intentions is less clear. Another view that is based primarily on anecdotal evidence is that superior problem resolution forges stronger links between customers and the corporation that would occur had no service problem arisen. Finally, Athanasopoulou (2012) indicate that enhancing service quality can increase favorable behavioral intentions and reduce unfavorable intentions. The findings show the significance of approaches that can direct behavioral intentions in the right directions, including struggling to meet customers' desired-service levels (rather than merely performing at their adequate service levels), emphasizing the prevention of service problems, and effectively resolving problems that do occur. Hence, we hypothesize:

H4: Service Quality as a Functional Perceived Value Dimension is associated with Customer Engagement.

Emotional dimensions. Novelty perceptions. Berylne (1950) is one of the early studies to examine novelty-seeking in psychology. As Berlyne suggests, novelty could grasp the key to our understanding of a little of the convoluted levels of human motivation. Accordingly, novelty (change from routine, getaway, thrill, adventure, surprise and boredom alleviation) is one of the blunt motivations steering services clients find for new and disparate experiences (Bello \& Etzel, 1985; Lee \& Crompton, 1992; Unger \& Kernan, 1983). Virvilaite et al. (2015)'s work in psychology indicates that arousal or novelty-seeking is time- and place- specific. If novelty is wanted by experiential service customers, next extra novel experiences must result in higher perceptions of value. Thus, we predict:

H5: Novelty as an emotional perceived value dimension is associated with Customer Engagement.

Control perceptions. In service settings, customers experience a sequence of connections with personnel and the physical atmosphere during the consumption experience as mentioned by Bateson (2000). These connections may lead to higher levels of consumer involvement in the service procedure, which at that point opens up a need for control. The concept of control is an integral portion of human motivations. Hence, we hypothesize:

H6: Control as an emotional perceived value dimension is associated with Customer Engagement

Hedonics perceptions. Most human behavior is basically pleasure-seeking (Holbrook \& Hirschman, 1982), and consumers typically desire a feeling of pleasure from a service experience. The hedonic consumption paradigm suggests that in many situations' consumers seek 'fun, amusement, fantasy, arousal, sensory stimulation and enjoyment" Virvilaite et al. (2015). Holbrook and Hirschman further debate that the degree of hedonic responses varies across product categories. In Petrick's (2003) study, emotional responses (i.e., how a service makes one feel) were directly related to the perceived value associated with the service experiences.

$\mathrm{H7}$ : Hedonics Value is associated with Customer Engagement.

Social Value. According to Virvilaite et al. (2015), Social value has been defined as perceptual benefits acquired from a product's association with social class status, or a specific social group. Therefore, it can be concluded that the more benefits in terms of social benefits the customers have (e.g. belonging or admiration), the more likely they will engage in helping behavior. Thus, we predict:

$\mathrm{H} 8$ : Social Value is associated with Customer Engagement

Customer Engagement and Brand Loyalty. The process of engagement traces the spatial development of loyalty by mapping the relationships between the constructs of calculative commitment, affective commitment, involvement, and trust as customers' development from being new to a service brand to becoming repeated buyers of specific service brands (Mabkhot et al., 2016). This approach therefore emphasizes the role of specific psychological mediating variables in the development of a more enduring state of brand loyalty, and in so doing, differentiates truly loyal customers from those who have limited brand sensitivity and repeat purchase due to a state of inertia or spurious loyalty (Odin et al., 2001).

H9: Successful Customer Engagement is associated with Brand loyalty.

Methodology. Measures and Survey Instrument. The study used questionnaires collected through 
using personal interviews with the respondents in different healthcare centers around Cairo and Giza. Unlike services that require brief interactions (e.g. retail banking), social benefits are more likely to occur within services that require a high level of repeated personal interactions (e.g. GYM). It is important to note that all the measurement scales used were derived from previously validated scales and were pre-tested through piloting by academic experts in the field of marketing and statistics. The questionnaire first included a filtering question about whether the respondent is a member of a healthcare center or not. If it was responded by "Yes", the respondent shall proceed to questions specifying their frequency of visiting the healthcare center, along with specifying which healthcare center they are visiting. Also, the questionnaire encompassed 54 statements measure the variables under study on a 5-point Likert scale ranging where the respondents were asked to report on their agreement on each statement with a scales ranging from strongly disagree to strongly agree.

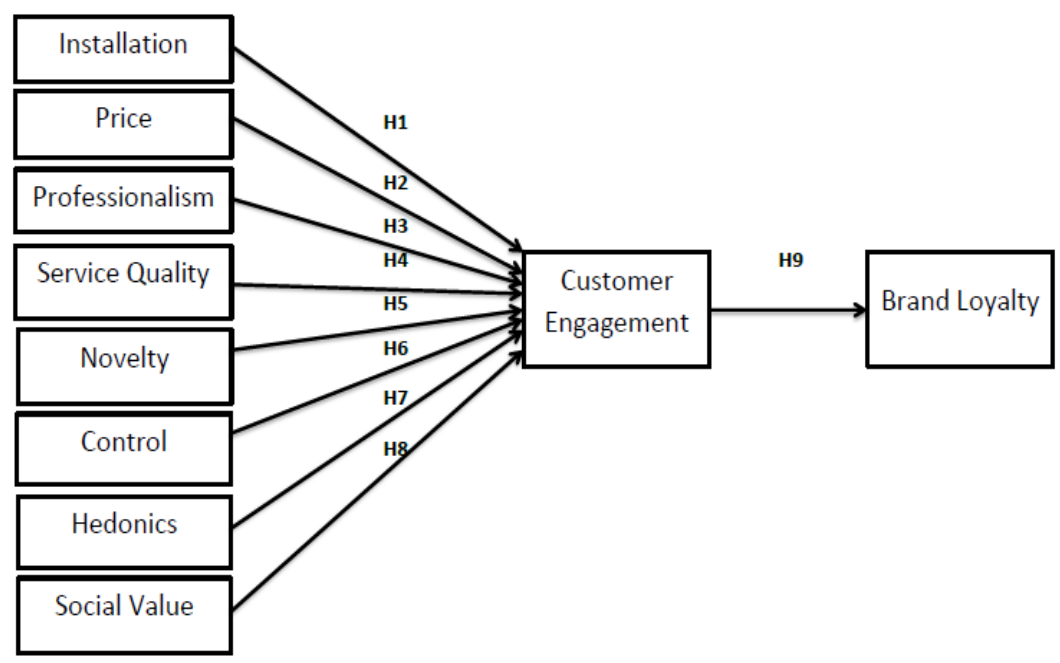

Figure 1 - Research framework

Functional value (installation), functional value (professionalism), and social value were adapted from S"Sanchez et al., (2006). Emotional values (novelty, control, and hedonics) were adapted from the studies of Otto, (1997) and Otto and Ritchie, (1996). Functional value (price) was adopted from Ralston (1999). Functional value (Service quality) was adapted from Gallarz-Saura (2006). Customer engagement was adopted from Byrne (1994). Customer loyalty (Brand loyalty) was adopted from Mols (1998). All of these constructs are reflectively measured. Finally, the questionnaire inquired about demographic information using five questions tackling Frequency of visits, age, gender, educational level and occupation. A few items were changed slightly after the pre-test stage because they were misinterpreted by the respondents. The measures' validity and reliability data are presented in the results section.

Sample selection and data collection. This study was conducted in the Egyptian Context and it examined the healthcare centers users' behaviour, so it is important to point out that there is no population frame for the targeted population, who are health care centers users in Egypt during the period of study. A non-probability convenience sampling was used to select a sample representative of the population. The choice of the sample focuses on the segment of young adults between 16 years and 45 years. The study focused on the adolescents, youths and adults since they represent the majority of the healthcare centers users according to the context understudy (Based on the exploratory research conducted). This 
research targeted 400 healthcare centers users (Hair et al., 2010). Caution has been given to include users with different frequency of visiting healthcare centers along with taking into consideration other demographic factors such as: gender, age, educational level and employment, to fairly represent the users of healthcare centers. Table 1 describes the sample characteristics. Both women $(38.7 \%)$ and men $(61.3 \%)$ were represented in the sample; the majority of the sample chosen was characterized to be university students with age ranging between 16 to 25 , who are definitely unemployed and visit the healthcare center more than once a week. Also, almost half of the sample $(46 \%)$ goes to health care center two times and more weekly. In addition, $57.5 \% \%$ of respondents visit top five healthcare centers' brands in Egypt as the most luxurious healthcare center brands.

Table 1 - Sample characteristics

\begin{tabular}{|c|c|c|c|}
\hline Category & Percentage & Category & Percentage \\
\hline \multicolumn{2}{|l|}{ Frequency of Visits } & \multicolumn{2}{|l|}{ Occupation } \\
\hline Rarely & $28.3 \%$ & Unemployed & $69.5 \%$ \\
\hline Once a week or less & $25.6 \%$ & Private Sector Employee & $21.3 \%$ \\
\hline Two times and more & $46.3 \%$ & Public Sector Employee & $2.8 \%$ \\
\hline \multicolumn{2}{|c|}{ Name of Healthcare Center } & Professional & $0.3 \%$ \\
\hline Top five brands & $57.5 \%$ & Businessman/woman & $5.8 \%$ \\
\hline Others & $42.5 \%$ & Retired & $0.5 \%$ \\
\hline \multicolumn{2}{|l|}{ Gender } & \multicolumn{2}{|l|}{ Educational Level } \\
\hline Male & $61.3 \%$ & High School & $2.3 \%$ \\
\hline Female & $38.8 \%$ & University Student & $74.0 \%$ \\
\hline \multicolumn{2}{|l|}{ Age } & Bachelor Degree & $16.3 \%$ \\
\hline 25 or less & $80.3 \%$ & \multirow{2}{*}{ Post-Graduate Degree } & \multirow{2}{*}{$7.5 \%$} \\
\hline More than 25 & $19.7 \%$ & & \\
\hline
\end{tabular}

As the data were collected from a single source, common method bias could affect the relationships between the constructs (Podsakoff, et al., 2003). The common method bias was tested using Harman's one-factor test. The Exploratory Factor Analysis (EFA) of all measurement items extracted eleven factors explaining $62 \%$ of the total variance using SPSS v. 25 . However, the first factor explained only $31.17 \%$ of the total variance. Thus, common method bias is not a major concern in this study. The eleven factors for the ten constructs in the abovementioned theoretical model mean guides authors to specify all constructs of the model as first-order measurement level except customer engagement which will be measured at second-order level.

Results. We used SPSS v.25 to describe the sampling profile, while Smart PLS v. 3.2.7 (Ringle et al., 2015) is used to conduct Structure Equation Modeling using Partial Least Squares (SEM-PLS) for research model evaluation and research hypotheses testing purposes. Confirmatory Factor Analysis (CFA) was used to evaluate the measurement model. Table (2) illustrates the results of CFA. Table (2) show that all measurement model constructs' convergent validity is established since the AVE for each construct is higher than 0.5. (Hair et al., 2010; 2014; 2016). Also, discriminant validity has been established according to $\mathrm{HTMT}_{0.85}$ and $\mathrm{HTMT}_{0.9}$ and their inference (Henseler et al., 2015).

Thus, researcher tested the constructed reliability using Cronbach's alpha and Composite Reliability $(\mathrm{CR})$, both indicated the reliability of all constructs since all parameters are higher than 0.6. (Malhotra, 2010). Although, Social value seems to lack of internal consistency as its Cronbach's alpha less than 0.6. however, one of the main disadvantages of Cronbach's alpha is it is sensitive to a number of items per construct, with short scales that have less than 10 items it is common to find it less than 0.6, and that is the case of Social value. 
Y. Mohsen, M. Hussein, A. Mahrous. Perceived Service Value, Customer Engagement and Brand Loyalty in Health Care Centres in Egypt

Table 2 - CFA results

\begin{tabular}{|c|c|c|c|c|}
\hline \multirow[b]{2}{*}{ Constructs } & Validity & Reliability & & \multirow[b]{2}{*}{$\mathbf{R}^{2}$} \\
\hline & $\begin{array}{l}\text { Average Variance } \\
\text { Extracted (AVE) }\end{array}$ & Cronbach's Alpha & $\begin{array}{c}\text { Composite } \\
\text { Reliability (CR) }\end{array}$ & \\
\hline Brand Loyalty & 0.505 & 0.800 & 0.858 & 0.554 \\
\hline Control & 0.513 & 0.763 & 0.840 & \\
\hline Customer Eng. & 0.507 & 0.805 & 0.860 & 0.417 \\
\hline Hedonics & 0.534 & 0.703 & 0.819 & \\
\hline Installation & 0.656 & 0.736 & 0.851 & \\
\hline Novelty & 0.586 & 0.764 & 0.850 & \\
\hline Price & 0.765 & 0.694 & 0.867 & \\
\hline Professionalism & 0.632 & 0.854 & 0.895 & \\
\hline Service Quality & 0.540 & 0.857 & 0.891 & \\
\hline Social Value & 0.672 & $0.513(0.345)$ & 0.804 & \\
\hline
\end{tabular}

So, instead, we report Social value mean of inter-item correlations value that is 0.345 that is fall in the rage between 0.2 and 0.4 , therefore, Social value has internal consistency (Briggs and Cheek, 1986). Thus, the current structural model explains $55.4 \%$ of Brand loyalty, and $41.7 \%$ of Customer Engagement.

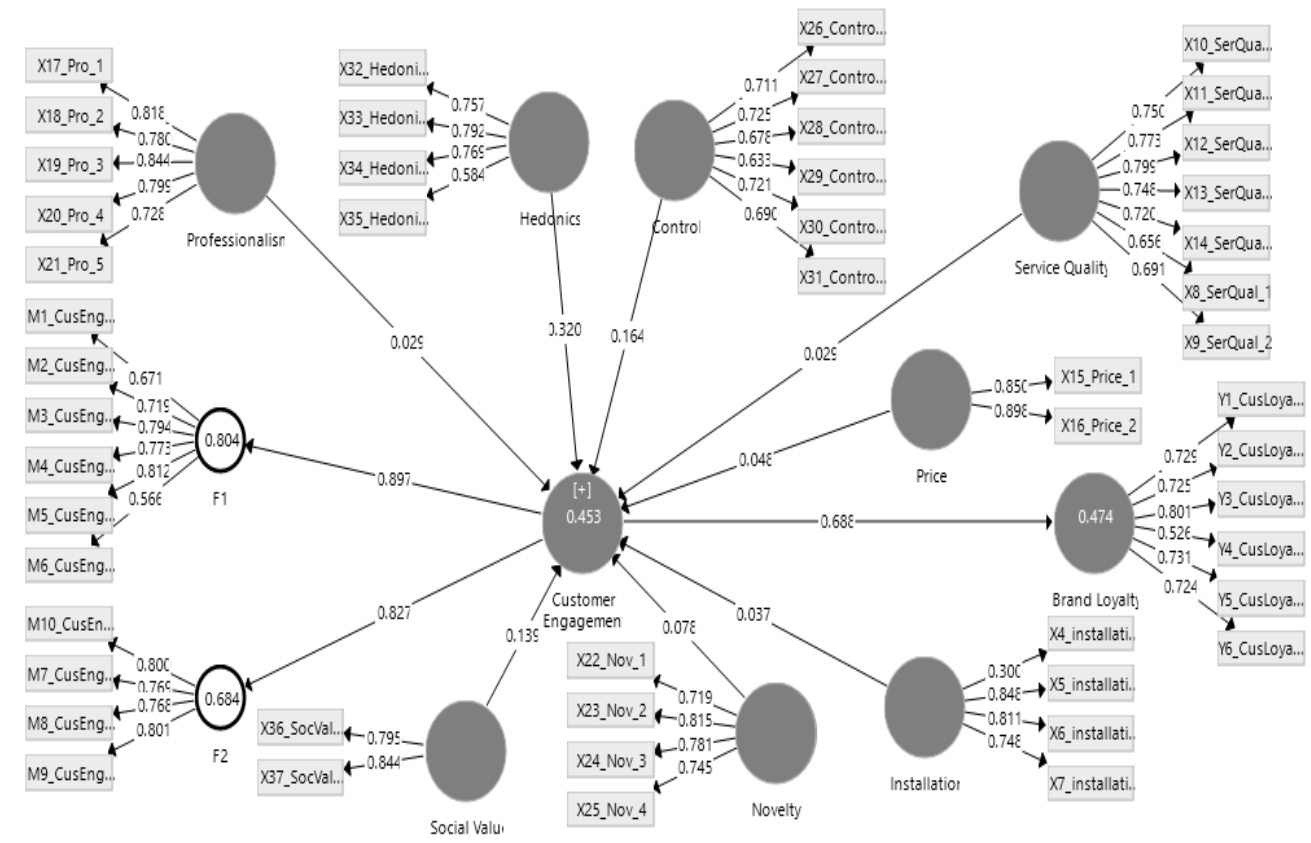

Figure 2 - Theoretical model

After the measurement model has been assessed, hypotheses testing will be conducted using a bootstrapping procedure of 5000 subsamples. First, we started by the direct hypotheses testing as in table 3.

Then indirect mediation test - hypotheses testing as in table (4). Finally, the indirect moderation test will be conducted as in table (5). As can be seen from the table (3), $\mathrm{H} 1$ to $\mathrm{H} 5$ is not significantly supported at confidence level $95 \%$. On the other hand, $\mathrm{H} 6$ has been supported with confidence level $95 \%$. Thus, 
control has a positive effect on customer engagement by $16.3 \%$. Also, $\mathrm{H} 7$ has been supported with confidence level $99.9 \%$. Therefore, hedonics has a positive effect on customer engagement by $26.4 \%$. In addition, $\mathrm{H} 8$ has been supported with confidence level $99 \%$. Moreover, H9 has been supported with confidence level $99.9 \%$.

Table 3 - Direct hypotheses testing

\begin{tabular}{|c|l|c|c|c|c|}
\hline H & \multicolumn{1}{|c|}{ Direct path } & $\beta$ & $t$-value & $P$. values & Result \\
\hline H1 & installation -> Customer Engagement & 0.052 & 0.906 & 0.365 & Not supported \\
\hline H2 & Service Quality -> Customer Engagement & 0.056 & 0.649 & 0.517 & Not supported \\
\hline H3 & Price -> Customer Engagement & -0.001 & 0.016 & 0.987 & Rejected \\
\hline H4 & Professionalism -> Customer Engagement & 0.079 & 1.160 & 0.246 & Not supported \\
\hline H5 & Novelty -> Customer Engagement & 0.058 & 0.978 & 0.328 & Not supported $^{*}$ \\
\hline H6 & Control -> Customer Engagement & 0.163 & 2.416 & 0.016 & Supported $^{*}$ \\
\hline H7 & Hedonics -> Customer Engagement & 0.264 & 4.339 & 0.000 & Supported $^{* * *}$ \\
\hline H8 & Social value -> Customer Engagement & 0.139 & 2.661 & 0.008 & Supported $^{* *}$ \\
\hline H9 & Customer Engagement -> Brand Loyalty & 0.486 & 10.859 & 0.000 & Supported $^{* * *}$ \\
\hline
\end{tabular}

${ }_{* * *}$ Confidence level is $99.9 \%$, Significance level $\mathrm{P}$ value $<0.001$, $\mathrm{t}$ value \pm 3.29 ; ${ }^{* *}$ Confidence level is $99 \%$, Significance level $P$ value $<0.01$, t value \pm 2.58 ; ${ }^{*}$ Confidence level is $95 \%$, Significance level $P$ value $<0.05$, $\mathrm{t}$ value \pm 1.96 . redetected refers to not supported and wrong direction

With respect to the mediation analysis, Preacher and Hayes $(2004 ; 2008)$ approach as illustrated in Nitzl et al., (2016) has been followed. Firstly, the direct relationships from all perceived value dimensions on customer loyalty, without customer engagement presence, should be significant as demonstrated in step (1) (see table. 4). Price, Novelty, and Control have been significant. Secondly, the significant relationships in step (1) will proceed to step (2) where the mediator role included in the model.

Table 4 - Indirect hypotheses testing - mediation test

\begin{tabular}{|c|c|c|c|}
\hline \multirow{10}{*}{$\begin{array}{l}\bar{\Xi} \\
\stackrel{0}{0} \\
\dot{c}\end{array}$} & \multicolumn{3}{|l|}{ Direct Path coefficients without mediator } \\
\hline & Exogenous variable $->$ Endogenous variable & $\beta_{(\text {t-value })}$ sig. & Decision \\
\hline & installation -> Brand Loyalty & $0.049_{(0.825)} 0.410$ & Non-mediation \\
\hline & Service Quality -> Brand Loyalty & $0.164(1.854)^{0.064}$ & Non-mediation \\
\hline & Price -> Brand Loyalty & $0.112(2.012)^{0.044}$ & Go to step (2) \\
\hline & Professionalism -> Brand Loyalty & $-0.008(0.127)^{0.899}$ & Non-mediation \\
\hline & Novelty -> Brand Loyalty & $0.155(2.530)^{0.011}$ & Go to step (2) \\
\hline & Control -> Brand Loyalty & $0.166_{(2.642)}^{0.008}$ & Go to step (2) \\
\hline & Hedonics -> Brand Loyalty & $0.124_{(1.951)^{0.051}}$ & Non-mediation \\
\hline & Social value -> Brand Loyalty & $0.062(1.185)^{0.236}$ & Non-mediation \\
\hline \multirow{5}{*}{$\begin{array}{l}\text { a } \\
\stackrel{a}{d} \\
\dot{\omega}\end{array}$} & \multicolumn{3}{|c|}{ Indirect Path coefficients with the mediator = (exogenous to mediator. mediator to endogenous) } \\
\hline & Exogenous variable -> Mediator $->$ Endogenous variable & $\left.\beta_{(t-v a l u e)}\right)^{\text {Sig. }}$ & Decision \\
\hline & Price -> Customer Engagement -> Brand Loyalty & $0.000(0.016)^{0.987}$ & Non-mediation \\
\hline & Novelty -> Customer Engagement -> Brand Loyalty & $0.028(0.970)^{0.332}$ & Non-mediation \\
\hline & Control -> Customer Engagement -> Brand Loyalty & $0.079(2.364)^{0.018}$ & Go to step (3) \\
\hline \multirow{3}{*}{$\begin{array}{l}\text { ल) } \\
\text { बे } \\
\text { के }\end{array}$} & \multicolumn{3}{|c|}{ Total Path coefficients with the mediator = (Direct + Indirect effect) } \\
\hline & Exogenous variable $->$ Mediator $->$ Endogenous variable & $\beta_{\text {(t-value) }}$ sig. & Decision \\
\hline & Control -> Customer Engagement -> Brand Loyalty & $0.165(2.652)^{0.008}$ & Go to step (4) \\
\hline \multirow{3}{*}{$\begin{array}{l}\text { 于 } \\
\text { के } \\
\text { के }\end{array}$} & \multicolumn{3}{|c|}{ Mediation effect Variance Accounted For VAF= (Indirect effect / Total effect) } \\
\hline & Exogenous variable $->$ Mediator $\rightarrow>$ Endogenous variable & VAF & Result \\
\hline & Control -> Customer Engagement -> Brand Loyalty & $0.079 / 0.165=0.47 .8$ & Partial mediation \\
\hline
\end{tabular}



Centres in Egypt

Next, the indirect relationships from the three abovementioned exogenous variables on Customer loyalty should be significant. Only Control has a significant indirect relationship on loyalty through Customer Engagement. Step (3) procedure includes testing the total effect from the Control (the only variable that has a significant indirect relationship on loyalty) variable on Customer Loyalty. Finally, since the total effect for control variable is significant, the researcher should calculate the Variance Accounted For (VAF) value to determine exactly the effect size of the mediator though multiplying sig. indirect relationship by sig. total effect. VAF value indicates one of the three levels of mediation. If VAF is less than 0.2 , the relationship is not mediated. Form $0.2-0.8$, the relationship is partially mediated. Finally, if VAF is higher than 0.8, the relationship is fully mediated (Hair et al., 2014; Hayes, 2013). Therefore, Customer engagement partially mediates the relationship between Control and Customer loyalty by $47.8 \%$.

To test the indirect moderation effects, Multi Group Analysis (MGA) methodology has been followed (Hair et al., 2010; 2014). Table (5) indicates the significant difference between respondents in regarding the relationship between control on customer engagement because of their visits frequencies. Respondents who go to health care centre rarely are significantly different from those who go repeatedly, by $41.1 \%$ from once a weak with confidence level $95 \%$ and $44.4 \%$ from two visits and more a weak with confidence level $99 \%$. Since the effect of control on customer engagement in rarely visitors is not significant negative by $13.6 \%$. Where, the same relationship in once a weak group is significant positive by $27.5 \%$, and $30.9 \%$ for more two or more visits' a week group. Another significant effect from visits frequency variable is on the relationship between service quality and customer engagement by $55.8 \%$ with confidence level $95 \%$. Since the rarely visitors have a significant positive effect on service quality on customer engagement by $40.1 \%$ where once a week group has no significant negative relationship with $15.7 \%$.

Moreover, the brand name of health care centre has a significant moderation effect on the relationship between Hedonics and Customer Engagement. Since the top five healthcare brands' visitors are significantly different from other healthcare brands' visitors by $24.5 \%$ with confidence level $95 \%$. Although both groups have significant positive relationships, the magnitude of each relationship makes the significant difference between those groups. Top five brands group has $40.4 \%$ percentage of Hedonics effect on Customer Engagement. Where, other brands group has only $15.9 \%$ of the same relationship.

Table 5 - Indirect hypotheses testing - Multi-Group Analysis moderation test

\begin{tabular}{|c|c|c|c|c|c|c|c|c|c|}
\hline \multicolumn{10}{|c|}{ Visits frequencies } \\
\hline \multirow[b]{2}{*}{ Path } & \multicolumn{3}{|c|}{ Once a week or less } & \multicolumn{3}{|c|}{ Rarely } & \multicolumn{3}{|c|}{$\begin{array}{c}\text { (|Once a week or less - } \\
\text { Rarely } \mid)\end{array}$} \\
\hline & $\begin{array}{c}\text { Path } \\
\text { Coefficient }\end{array}$ & $\begin{array}{c}\mathrm{t}- \\
\text { Value }\end{array}$ & $\begin{array}{c}p- \\
\text { Value }\end{array}$ & $\begin{array}{c}\text { Path } \\
\text { Coefficient }\end{array}$ & $\begin{array}{c}\text { t- } \\
\text { Value }\end{array}$ & $\begin{array}{c}p- \\
\text { Value }\end{array}$ & $\begin{array}{c}\text { Path } \\
\text { Coefficient- } \\
\text { diff }\end{array}$ & $\begin{array}{c}\mathrm{t}- \\
\text { Value }\end{array}$ & $\begin{array}{c}p- \\
\text { Value }\end{array}$ \\
\hline Control -> Customer Engagement & 0.275 & 2.621 & 0.009 & -0.136 & 0.934 & 0.351 & 0.411 & 2.262 & 0.025 \\
\hline Service Quality -> Customer Engagement & -0.157 & 0.913 & 0.362 & 0.401 & 2.718 & 0.007 & 0.558 & 2.486 & 0.014 \\
\hline \multicolumn{10}{|c|}{ Visits frequencies } \\
\hline \multirow[b]{2}{*}{ Path } & \multicolumn{3}{|c|}{ Two times and more } & \multicolumn{3}{|c|}{ Rarely } & \multicolumn{3}{|c|}{$\begin{array}{c}\text { (|Two times and more - } \\
\text { Rarely } \mid)\end{array}$} \\
\hline & $\begin{array}{c}\text { Path } \\
\text { Coefficient }\end{array}$ & $\begin{array}{c}\mathrm{t}- \\
\text { Value }\end{array}$ & $\begin{array}{c}p- \\
\text { Value }\end{array}$ & $\begin{array}{c}\text { Path } \\
\text { Coefficient }\end{array}$ & $\begin{array}{c}\mathrm{t}- \\
\text { Value }\end{array}$ & $\begin{array}{c}p- \\
\text { Value }\end{array}$ & $\begin{array}{c}\text { Path } \\
\text { Coefficient- } \\
\text { diff }\end{array}$ & $\begin{array}{c}\text { t- } \\
\text { Value }\end{array}$ & $\begin{array}{c}p- \\
\text { Value }\end{array}$ \\
\hline Control -> Customer Engagement & 0.309 & 3.267 & 0.001 & -0.136 & 0.899 & 0.369 & 0.444 & 2.641 & 0.009 \\
\hline \multicolumn{10}{|c|}{ Healthcare Centre brand name } \\
\hline & \multicolumn{3}{|c|}{ Top five brands } & \multicolumn{3}{|c|}{ Others } & \multicolumn{3}{|c|}{ (| Top five brands - Others $\mid)$} \\
\hline Path & $\begin{array}{c}\text { Path } \\
\text { Coefficient }\end{array}$ & $\begin{array}{c}\mathrm{t}- \\
\text { Value }\end{array}$ & $\begin{array}{c}p- \\
\text { Value }\end{array}$ & $\begin{array}{c}\text { Path } \\
\text { Coefficient }\end{array}$ & $\begin{array}{c}\text { t- } \\
\text { Value }\end{array}$ & $\begin{array}{c}p- \\
\text { Value }\end{array}$ & $\begin{array}{c}\text { Path } \\
\text { Coefficient- } \\
\text { diff }\end{array}$ & $\begin{array}{c}\text { t- } \\
\text { Value }\end{array}$ & $\begin{array}{c}p- \\
\text { Value }\end{array}$ \\
\hline Hedonics -> Customer Engagement & 0.159 & 2.113 & 0.035 & 0.404 & 4.190 & 0.000 & 0.245 & 2.039 & 0.042 \\
\hline
\end{tabular}


Table 5

\begin{tabular}{|c|c|c|c|c|c|c|c|c|c|}
\hline \multicolumn{10}{|c|}{ Age } \\
\hline \multirow[b]{2}{*}{ Path } & \multicolumn{3}{|c|}{25 or less } & \multicolumn{3}{|c|}{ More than 25} & \multicolumn{3}{|c|}{$\begin{array}{l}\text { (|Less than } 25 \text { - More than } \\
25 \mid)\end{array}$} \\
\hline & $\begin{array}{c}\text { Path } \\
\text { Coefficient }\end{array}$ & $\begin{array}{c}\mathrm{t}- \\
\text { Value }\end{array}$ & $\begin{array}{c}p- \\
\text { Value }\end{array}$ & $\begin{array}{c}\text { Path } \\
\text { Coefficient }\end{array}$ & $\begin{array}{c}\mathrm{t}- \\
\text { Value }\end{array}$ & $\begin{array}{c}p- \\
\text { Value }\end{array}$ & $\begin{array}{c}\text { Path } \\
\text { Coefficient- } \\
\text { diff }\end{array}$ & $\begin{array}{l}\text { t- } \\
\text { Value }\end{array}$ & $\begin{array}{c}p- \\
\text { Value }\end{array}$ \\
\hline Professionalism -> Customer Engagement & 0.115 & 1.272 & 0.204 & -0.306 & 1.345 & 0.179 & 0.409 & 2.521 & 0.012 \\
\hline Service Quality -> Customer Engagement & -0.003 & 0.039 & 0.969 & 0.406 & 2.627 & 0.009 & 0.421 & 1.969 & 0.050 \\
\hline
\end{tabular}

Gender, education level, and occupation have no differences between their subgroups.

Finally, age has a significant effect on two of the proposed relationships. First, 25 years or fewer groups are significantly differing from more than 25 years group regarding the relationship of professionalism on customer engagement by $40.9 \%$ confidence level. Although both groups have not a significant relationship, the direction of each group plays the vital role for this distinction. 25 or less group has a positive effect by $11.5 \%$ where another group has a negative effect by $30.6 \%$. Second, age significantly moderates the relationship between service quality and customer engagement by $42.1 \%$ with confidence level $95 \%$. To clarify this difference, the 25 years or fewer groups has a negative not significant relationship by $0.3 \%$, where more than 25 years group has a significant positive relationship with $40.6 \%$.

Discussion and implications. This study focused on examining the effect of Cengiz \& Kirkbir (2007)'s eight dimensions of perceived value on customer engagement and customer loyalty. First, there is no significant relationship between installation, price, professionalism, service quality, as dimensions of the functional perceived value dimension, and Customer Engagement. Moreover, novelty as an emotional perceived value dimension has no significant relationship with customer engagement. However, control and hedonics as emotional perceived value dimensions have a significant relationship with customer engagement. Meanwhile, social value has a significant relationship with customer engagement. Finally, it is found that customer engagement and brand loyalty are significantly associated. With respect to the mediation analysis, the results show that only control has significant indirect relationship on loyalty through Customer Engagement. Also, customer engagement partially mediates the relationship between Control and Customer loyalty by $47.8 \%$. Finally, age, frequency of health care centres visits and health care centres' brand name moderates the relationship between some aspects of perceived value and customer engagement. The brand name of health care center has a significant moderation effect on the relationship between Hedonics and Customer Engagement. Age significantly moderates the relationship between service quality and customer engagement. Also, age significantly moderates the relationship between professionalism on customer engagement. Finally, healthcare visits frequency moderates the relationship between service quality and customer engagement.

In addition, implementing this study in the Egyptian context which lacks similar studies, would provide a better understanding of the Egyptian Healthcare Centres' users behavior in general, and how their loyalty might be affected by a different variable in specific. This study would also help marketing practitioners, healthcare centers and similar service providers create more effective service delivery process that would positively influence their perceived value and similarly their loyalty. Also, the different contextual variables understudy could be used as a guide for them to improve the healthcare service level to gain better value proposition to deliver to their customer, therefore, enhancing the healthcare centers' service effectiveness in the Egyptian Market.

Limitations and Future Research. The findings of this research need to be viewed in light of their limitations. First, the sample characteristics have a majority of male university students below 25 years old. Therefore, it is recommended for future researchers to focus on studying the female users of healthcare centers in the Egyptian context, as a rapidly growing population that requires academic 
attention to gain further insight and provide a better understanding on its female user's patterns and preferences. Moreover, empirical research is needed to study the effect of contextual variables of perceived value (e.g. functional, emotional and social value dimensions) separately on customer loyalty.

Aaker D. (1991), Brand equity, La gestione del valore della marca., 50-70

Akhade G. et al. (2013), A review on Healthcare Service Quality Dimensions, The Institute of electrical and electronics, Inc. (IEEE), 126-135

Alhaddad A. (2015), A structural model of the relationships between brand image, brand trust and brand loyalty, Internationa Journal of Management Research and Reviews. 5.3, pp.137-144

Allen D. \& Willburn M. (2002), Linking customer and employee satisfaction to the bottom line: A comprehensive guide to establishing the impact of customer and employee satisfaction on the critical business outcome.

Al-Msallam, S. (2015), Customer satisfaction and brand loyalty in the hotel industry, European Scientific Journal, Special Edition, 7, 27, 34 .

Anderson E. \& Mittal V. (2000), Strengthening the satisfaction-profit chain, Journal of Service Research, 3(2), 107-120.

Athanasopoulou, P. (2012), Relationship quality in services: past, present and future, Customer-Centric Marketing Strategies: Tools for Building Organizational Performance, IGI Global, Hershey, PA, pp. 171 - 191.

Averill J. (1973), Personal control over aversive stimuli and its relationship to stress, Psychological Bulletin, 80(4), 286.

Bateson P. (2000), The biological evolution of cooperation and trust, Making and breaking cooperative relations. Trust: Making and breaking cooperative relations, electronic edition. Department of Sociology, University of Oxford, 14-30

Bello D. \& Etzel M. (1985), The role of novelty in the pleasure travel experience, Journal of Travel Research, 24(1), 20-26.

Berkley B. \& Gupta A. (1994), Improving service quality with information technology, International journal of information management, 14(2), 109-121.

Berlyne D. (1950), Novelty and curiosity as determinants of exploratory behavior, British Journal of Psychology. General Section, 41(1-2), 68-80.

Berlyne D. (1967), Arousal and reinforcement, Nebraska symposium on motivation $57-71$

Bitner M. (1992), Servicescapes: The impact of physical surroundings on customers and employees, The Journal of Marketing

Bloemer J. \& Kasper H. (1995), The complex relationship between consumer satisfaction and brand loyalty, Journal of economic psychology, 16(2), 311-329.

Bolton R. \& Drew J. (1991), A multistage model of customers' assessments of service quality and value, Journal of consumer research, 17(4), 375-384.

Bolton R. \& Drew J. (1992), Mitigating the effect of service encounters, Marketing Letters, 3(1), 57-70.

Boulding W. et al. (1993), A dynamic process model of service quality: from expectations to behavioral intentions, Journal of marketing research, $30(1), 7$.

Bowden J. (2009), The process of customer engagement: A conceptual framework, Journal of Marketing Theory and Practice, 17(1), 63-74.

Briggs, S.R. \& Cheek, J.M. (1986). The role of factor analysis in the development and

evaluation of personality scales. Journal of Personality, 54, 106-48.

Broderick A. \& Vachirapornpuk S. (2002), Service quality in internet banking: the importance of customer role, Marketing Intelligence \& Planning, 20(6), 327-335

Brodie, R.J. \& Hollebeek, L. (2011), "Advancing and consolidating knowledge about customer engagement", Journal of Service Research, Vol. 14 No. 3, pp. 283-284

Brogowicz A. et al. (1990), A synthesized service quality model with managerial implications, International Journal of Service Industry Management, 1(1), 27-45.

Brown T. et al. (1993), Improving the measurement of service quality, Journal of Retailing, 69(1), 127-139.

Buzzell R. \& Gale B. (1987), The PIMS Principles: Linking strategy to performance.

Carbone L. \& Haeckel S. (1994), Engineering customer experiences, Marketing Management, 3(3), 8

Caruana A. \& Fenech N. (2005), The effect of perceived value and overall satisfaction on loyalty: A study among dental patients, Journal of Medical Marketing: Device, Diagnostic and Pharmaceutical Marketing, 5(3), 245-255.

Cengiz E. \& Kirkbir F. (2007), Customer perceived value: the development of a multiple item scales in hospitals, Problems and Perspectives in Management, 5(3 (continued)), 252.

Chang T. \& Wildt A. (1994), Price, product information, and purchase intention: An empirical study, Journal of the Academy of Marketing Science, 22(1), 16-27

Chen P. \& Hu H. (2010), How determinant attributes of service quality influence customer-perceived value: an empirical investigation of the Australian coffee outlet industry, International, Journal of Contemporary Hospitality Management, 29(3), 405412.

Cowles D. (1997), The role of trust in customer relationships: asking the right questions, Management Decision, 35(4), 273- 
282.

Cravens D. et al. (1988), Marketing's role in product and service quality, Industrial Marketing Journal, 17(4), 285-304.

Cronin J. \& Taylor S. (1992), Measuring service quality: a reexamination and extension, The journal of marketing, 55-68.

Cronin J. et al. (2000), Assessing the effects of quality, value, and customer satisfaction on consumer behavioral intentions in service environments, Journal of Retailing, 76(2), 193-218.

Cusmano, M.A. (2010), Staying Power, Oxford University Press.

Cusmano. M.A. (2008), The changing software business: Moving from Products to Services. Computer, 41(1), $20-27$.

Dabholkar P. (1994), Incorporating choice into an attitudinal framework: analyzing models of mental comparison processes, Journal of Consumer Research, 21(1), 100-118.

Dabholkar P. (1996), Consumer evaluations of new technology-based self-service options: an investigation of alternative models of service quality, International Journal of research in Marketing, 13(1), 29-51.

Dabholkar P. et al. (2000), A comprehensive framework for service quality: an investigation of critical conceptual and measurement issues through a longitudinal study, Journal of Retailing, 76(2), 139-173.

Davis S. (2002), Brand Asset Management2: how businesses can profit from the power of brand, Journal of Consumer Marketing.

Dick A. \& Basu K. (1994), Customer loyalty: toward an integrated conceptual framework, Journal of the academy of marketing science, 22(2), 99-113. 51.

Doney P. \& Cannon J. (1997), An examination of the nature of trust in buyer-seller relationships, The Journal of Marketing, 35-

Douglas T. \& Fredendall L. (2004), Evaluating the demand management model of total quality in services, Decision Sciences, 35(3), 393-422.

Doyle P. \& Wong V. (1998), Marketing and competitive performance: an empirical study, European Journal of Marketing, 32(5/6), 514-535.

Fang, E., Palmatier, R. W., \& Steenkamp, J. B. E. (2008). Effect of service transition strategies on firm value. Journal of Marketing, 72(5), 1-14

Farmer J. (1988), A conceptual model of service quality, International Journal of Operations \& Productions Management, 8(6), 19-29.

Field, A. (2009). Discovering statistics using SPSS. Sage publications.

Fitzsimmons J. \& Sullivan R. (1982), Service operations management (pp. 195-7). New York: McGraw-Hill.

Fornell C. (1992), A national customer satisfaction barometer: The Swedish experience, The Journal of Marketing, 6-21.

Frost F. \& Kumar M. (2000), INTSERVQUAL-an internal adaptation of the GAP model in a large service organization, Journal of Services Marketing, 14(5), 358-377.

Giovanis A. et al. (2015), The role of service fairness in the service quality- relationship quality - customer loyalty chain: An empirical study, Journal of Service Theory and Practice, 25.6, pp.744-776

Grönroos C. (1990), Service management and marketing: managing the moments of truth in service competition, Journal of Business Research.

Grönroos C. (1982), An applied service marketing theory, European journal of marketing, 16(7), 30-41.

Grönroos C. (1994), A service quality model and its marketing implications, European Journal of marketing.

Gustafsson A. et al. (2005), The effects of customer satisfaction, relationship commitment dimensions, and triggers on customer retention, Journal of marketing, 69(4), 210-218.

Hair Jr, J. F., Hult, G. T. M., Ringle, C., \& Sarstedt, M. (2016). A primer on partial least squares structural equation modeling (PLS-SEM). Sage Publications.

Hair, J. F., Hult, G. T. M., Ringle, C., \& Sarstedt, M. (2014). A Primer on Partial Least Squares Structural Equation Modeling (PLS-SEM). Sage Publications.

Hair, J., Sarstedt, M., Ringle, C., and Mena, J. (2012), "An assessment of the use of partial least squares structural equation modeling in marketing research", Journal of the Academy of Marketing Science, Vol.40 No.3, pp.414-433.

Hair. Jr, Black, Babin, and Anderson (2010). Multivariate data analysis, 7th edition, Pearson Prentice Hall.

Hair. Jr, Black, Babin, and Anderson (2010). Multivariate data analysis, 7th edition, Pearson Prentice Hall.

Hair. Jr, Hult. M, Ringle. M, and Sarstedt (2014). A primer on partial least squares structure equation modeling (PLS-SEM),

SAGE Publications.

Hammond K. (1996), The erosion of repeat-purchase loyalty, Marketing Letters.

Harcar T. et al. (2006), Consumer's perceived value and buying behavior of store brands: An empirical investigation, The

Business Review, 5(2), 55-62.

Hayes, A. (2013), Introduction to Mediation, moderation and conditional process analysis: A regression-based approach, The

Guilford Press, New York.

Hays J. \& Hill A. (2001), A preliminary investigation of the relationships between employee motivation/vision, service learning, and perceived service quality, Journal of Operations Management, 19(3), 335-349.

Henseler, J., Ringle, C. and Sarstedt, M. (2015), "A new criterion for assessing discriminant validity in variance-based SEM", Journal of the Academy of Marketing Science, Vol.43, pp. 115-135. 
Henseler, J., Ringle, C. M., \& Sarstedt, M. (2015). A new criterion for assessing discriminant validity in variance-based structural equation modeling. Journal of the Academy of Marketing Science, 43(1), 115-135.

Heskett J. et al. (1994), Breaking the cycle of failure in services.

Hirschman E. \& Holbrook M. (1982), Hedonic consumption: emerging concepts, methods and propositions, The Journal of Marketing, 92-101.

Holbrook M. \& Corfman K. (1985), Quality and value in the consumption experience: Phaedrus rides again, Perceived quality, 31(2), 31-57.

Innis D. \& La Londe (1994), Customer service: the key to customer satisfaction, customer loyalty, and market share, Journal of Business Logistics.

Jacoby J.\& Kyner D. (1973), Brand loyalty vs. repeat purchasing behavior, Journal of Marketing research, 1-9.

Jones M. et al. (2000), Switching barriers and repurchase intentions in services, Journal of Retailing, 76(2), 259-274.

Keiningham T. \& Vavra T. (2001), The customer delight principle: Exceeding customers' expectations for bottom-line success.

McGraw-Hill.

Kimberley N. \& Härtel C. (2008), Employee/customer interface in a service crisis: Impact of senior management attributes and practices on customer evaluation, Journal of Management \& Organization, 14(02), 207-218.

Kline, R. B. (2015). Principles and practice of structural equation modeling. 2nd. Guilford Press.

Lai A. (1995), Consumer Values, Product Benefits and Customer Value: A Consumption Behavior Approach, Advances in consumer research. Volume 22.

Langevin R. (1988), Service quality: Essential ingredients, Review of Business

Lee Th. \& Crompton J. (1992), Measuring novelty seeking in tourism, Annals of tourism research, 19(4), 732-751.

Liljander V. \& Roos I. (2002), Customer-relationship levels-from spurious to true relationships, Journal of services marketing,

16(7), 593-614

Lovelock C. (1983), Classifying services to gain strategic marketing insights, The Journal of Marketing, 9-20.

Lusch R. \& Vargo S. (2006), Service-dominant logic: reactions, reflections and refinements, Marketing theory, 6(3), 281-288.

Mabkhot H.A. et al. (2016), The Antecedents of Automobile Brand Loyalty: Evidence from Malaysian, International Review of

Management and Marketing, 6.3

Malhotra, N. K. (2010). Marketing research: An applied orientation, 6th Global edition, Upper Saddle River, NJ: Pearson.

Malhotra, N. K. (2010). Marketing research: An applied orientation, 6th Global edition, Upper Saddle River, NJ: Pearson.

Mancarelli R. \& Riviere, A. (2015), Perceived value in B2B and B2C: A comparative approach and cross-fertilization, Marketing

Theory. 15.2, pp. 201 - 218

Mangold W. \& Babakus E. (1991), Service quality: The front-stage vs. the back-stage perspective, Journal of Services Marketing, 5(4), 59-70.

Marketing Science Institute (MSI) Research Priorities 2006, pp. 2, 4.

McDougall G. \& Levesque T. (2000), Customer satisfaction with services: putting perceived value into the equation, Journal of services marketing, 14(5), 392-410.

McEwen (2004), Exploring consumer status and conspicuous consumption, Journal of Consumer Behaviour, 4(1), 25-39.

Mellens M. et al. (1997), Decline and variability in brand loyalty, International Journal of Research in Marketing, 14(5), 405-420

Meuter M. \& Bitner M. (1998), Self-service technologies: extending service frameworks and identifying issues for research, American Marketing Association Conference Proceedings (Vol. 9, p. 12).

Meyer S. \& Collier D. (2001), An empirical test of the causal relationships in the Baldrige Health Care Pilot Criteria, Journal of Operations Management, 19(4), 403-426.

Mittal V. \& Kamakura W. (2001), Satisfaction, repurchase intent, and repurchase behavior: Investigating the moderating effect of customer characteristics, Journal of marketing research, 38(1), 131-142.

Monroe K. et al. (1998), The effects of price-comparison advertising on buyers' perceptions of acquisition value, transaction value, and behavioral intentions, The Journal of Marketing, 46-59.

Morgan R. \& Hunt S. (1994), The commitment-trust theory of relationship marketing, The journal of marketing, 20-38.

Morgan, D. L. (1998). Practical strategies for combining qualitative and quantitative methods: Applications to health research.

Qualitative health research, 8(3), 362-376.

Nitzl, C., Roldan, J. and Cepeda, G. (2016), "Mediation analysis in partial least squares path modeling: Helping researchers discuss more sophisticated models", Industrial Management \& Data Systems, Vol. 116, №. 9, pp.1849 - 1864. Odin Y. et al. (2001), Conceptual and operational aspects of brand loyalty: an empirical investigation, Journal of Business Research, 53(2), 75-84.

Oh H. (1999), Service quality, customer satisfaction, and customer value: A holistic perspective, International Journal of Hospitality Management, 18(1), 67-82.

Oliver R. (1999), Whence consumer loyalty?, The Journal of Marketing, 33-44.

Oliver R. et al. (1997), Customer delight: foundations, findings, and managerial insight, Journal of Retailing, 73(3), 311-336.

Oyewole P. (2002), Affective states of the consumer and satisfaction with services in the airline industry, Services Marketing

Quarterly, 23(4), 45-63.

Pallant, J. (2011). SPSS survival manual: a step by step guide to data analysis using SPSS. Crows Nest. New South Wales: 
Allen \& Unwin

Parasuraman A. et al. (1988), Servqual, Journal of Retailing, 64(1), 12-40.

Parasuraman A. (1985), A conceptual model of service quality and its implications for future research, The Journal of Marketing, 41-50.

Parasuraman A. et al. (1991), Refinement and reassessment of the SERVQUAL scale, Journal of Retailing, 67(4), 420.

Parasuraman A. et al. (1994), Reassessment of expectations as a comparison standard in measuring service quality: implications for further research, The Journal of Marketing, 67(4), 420.

Parasuraman A. et al. (1996), The behavioral consequences of service quality, The Journal of Marketing, 31-46.

Patterson P. \& Spreng R. (1997), Modelling the relationship between perceived value, satisfaction and repurchase intentions in a business-to-business, services context: an empirical examination, International Journal of service marketing, 8(5), 414-434.

Payne, A. F., Storbacka, K., \& Frow, P. (2008). Managing the co-creation of value. Journal of the academy of marketing science, 36(1), 83-96.

Petersen et al. (2005), Does function follow organizational form? Evidence from the lending practices of large and small banks, Journal of Financial Economics, 76(2), 237-269.

Petrick J. (2003), Measuring Cruise passengers' perceived value, Tourism Analysis, 7(3-4), 251-258.

Philip G. \& Hazlett S. (1997) The measurement of service quality: a new PCP attributes model, International Journal of Quality \& Reliability Management, 14(3), 260-286.

Podsakoff, P. M., MacKenzie, S. B., Lee, J. Y., \& Podsakoff, N. P. (2003). Common method biases in behavioral research: a critical review of the literature and recommended remedies. Journal of applied psychology, 88(5), 879.

Porter M. (1990), The competitive advantage of notions, Harvard business review.

Prahalad, C. K., \& Ramaswamy, V. (2004). Co-creation experiences: The next practice in value creation. Journal of interactive marketing, 18(3), 5-14

Preacher, K. and Hayes, A. (2004), "SPSS and SAS procedures for estimating indirect effects in simple mediation models", Behavior Research Methods, Instruments, \& Computers, Vol. 36 No.4, pp.717-731.

Preacher, K. and Hayes, A. (2008), "Asymptotic and re-sampling strategies for assessing and comparing indirect effects in multiple mediator models", Behavior Research Methods, Vol.40, No.3, pp. 879-891.

Reichheld F. et al. (2003), Winning customer loyalty is the key to a winning CRM strategy, Ivey business journal, 67(4), 1.

Richard M. \& Allaway A. (1993), Service quality attributes and choice behavior, Journal of Services Marketing, 7(1), 59-68.

Ringle, C. M., Wende, S., and Becker, J.-M. 2015. "SmartPLS 3." Boenningstedt: SmartPLS GmbH, http://www.smartpls.com.

Santos J. (2003), E-service quality: a model of virtual service quality dimensions, Managing Service Quality: An International Journal, 13(3), 233-246.

Sauer N. (2010), Brand community: drivers and outcomes, Psychology \& Marketing, 27(4), 347-368.

Schultz D. \& Bailey S. (2000), Customer/brand loyalty in an interactive marketplace, Journal of Advertising Research, 40(3), 41-52.

Sirdeshmukh D. et al (2002), Consumer trust, value, and loyalty in relational exchanges, Journal of marketing, 66(1), $15-37$.

Soteriou A. \& Starvrinides Y. (2013), An internal customer service quality data envelopment analysis model for bank branches, International Journal of Bank Marketing.

Spreng R. \& Mackoy R. (1996), An empirical examination of a model of perceived service quality and satisfaction, Journal of Retailing, 72(2), 201-214.

Sweeney J. et al. (1997), Retail service quality and perceived value: A comparison of two models, Journal of Retailing and Consumer Services, 4(1), 39-48.

Tabachnick, B. G., \& Fidell, L. S. (2007). Using multivariate statistics, 5th.Needham Height, MA: Allyn \& Bacon.

Teas R. (1993), Expectations, performance evaluation, and consumers' perceptions of quality, The journal of marketing, 18-34

Teece, David J. "Profiting from technological innovation: Implications for integration, collaboration, licensing and public policy." Research Policy 15.6 (1986): 285-305

Thaler R. (1985), Mental accounting and consumer choice, Marketing Science, 4(3), 199-214.

Unger L. \& Kernan J. (1983), On the meaning of leisure: An investigation of some determinants of the subjective experience, Journal of Consumer research, 9(4), 381-392.

Van Doorn J. et al. (2010), Customer engagement behavior: Theoretical foundations and research directions, Journal of Service Marketing, 13(3), 253-266.

Vargo, S. L., \& Lusch, R. F. (2008). Service-dominant logic: continuing the evolution. Journal of the Academy of Marketing Science, $36(1), 1-10$

Verhoef $P$. et al. (2002), The effect of relational constructs on customer referrals and number of services purchased from a multiservice provider: does age of relationship matter?, Journal of the Academy of Marketing Science, 30(3), 202-216.

Virvilaite R. et al. (2015), The relationships between consumer perceived value and loyalty, Transformations in Business and Economics. 14.1, 76-89.

Wong H. \& Merrilees B. (2015), An empirical study of the antecedent and consequences of brand engagement, Marketing Intelligence \& Planning, 33.4, 575-591

Woodruff R. \& Gardial S. (1996), Know your customer: New approaches to understanding customer value and satisfaction. 
Y. Mohsen, M. Hussein, A. Mahrous. Perceived Service Value, Customer Engagement and Brand Loyalty in Health Care Centres in Egypt

Woodruff R. (1997), Customer value: the next source for competitive advantage, Journal of the academy of marketing science, 25(2), 139-153.

Yeh C. \& et al. (2016), Predicting smartphone brand loyalty: Consumer value and consumer-brand identification perspective, International Journal of Information Management. 36.3, 245-257

Zeithaml C. (1998), The international expansion process of MNEs from developing countries: a case study of Thailand's CP Group, Asia Pacific Journal of Management, 15(2), 163-184.

Zeithaml V. (1988), Consumer perceptions of price, quality, and value: a means-end model and synthesis of evidence, The Journal of marketing, 2-22.

Zeithaml V. (2000), Service quality, profitability, and the economic worth of customers: what we know and what we need to learn, Journal of the academy of marketing science, 28(1), 67-85.

Й. Мохсен, Університет сучасних наук та мистецтв (Каїр, Єгипет);

X. M. Хуссейн, Університет Каїру (Каїр, Єгипет)

A. A. Махрос, Університет Каїру (Каїр, Єгипет).

Споживча цінність послуг, залучення споживачів та лояльність бренду оздоровчих центрів Єгипту

Метою даної статті є аналіз концепиії споживчої цінності, описаної вченими Сенгіз та Кіркбір (2007), з точки зору восьми ключових оціночних індикаторів впливу на залучення споживачів та рівень їх лояльності. Автори зазначають, що кожен з восьми індикаторів споживчої цінності послуг розглядався окремо у попередніх дослідженнях. Тому у иій статті представлено результати врахування сили дії усіх індикаторів споживчої цінності послуг на зростання кількості залучених клієнтів та рівня їх лояльності на прикладі оздоровчих иентрів Єзипту. Об'єкт дослідження було обрано виходячи з тендениії стрімкого зростання обсягу ринку оздоровчих послуг в Єгипті. Імпульсом зростання зазначеного ринку було залучення клієнтів до процесу формування асортименту та плану надання послуг: місячні програми з фітнесу, позитивні/негативні рекомендації конкретного оздоровчого иентру своїм друзям, родичам та іншим випадковим користувачам у соціальних мережах, а також отримання відчуття приналежності до конкретного оздоровчого центру. Окрім цього, у багатьох оздоровчих центрах також було створено активний механізм отримання скарг та залучення клієнтів до процесу вирішення виявлених проблем. Запроваджені зміни в системі надання оздоровчих послуг призвело до активізації позитивних поведінкових намірів клієнтів. Емпіричні результати роботи грунтуються на анкетуванні через особисті інтерв'ю з респондентами у різних оздоровчих центрах. Дослідженням охоплено 400 користувачів оздоровчих центрів з цільовою групою - підлітки, молодь та доросле населення. Крім того, було розелянуто вплив бренду оздоровчого центру на взаємозв'язок між задоволенням і рівнем залучення клієнтів. Визначено вплив віку цільової аудиторії на взаємозв'язок між якістю послуг і рівнем залучення клієнтів. Авторами перевірено вплив рівня залучення клієнтів на взаємозв'язок між контролем та лояльністю споживачів.

Ключові слова: споживачі, корисність, залучення споживачів, послуги, лояльність бренду, оздоровчі центри. 